\title{
Mineral-salt supplement does not attenuate tall larkspur (Delphinium barbeyi) toxicosis in cattle
}

\author{
JAMES A. PFISTER, CARL D. CHENEY, DALE R. GARDNER, AND GARY D. MANNERS
}

\begin{abstract}
Pfister and Gardner are with the USDA-ARS Poisonous Plant Research Labatory, Logan, Ut. 84341; Cheney is with the Dept. of Psychology, Utah State University, Logan, Utah 84322; Manners is with the USDA-ARS Western Regional Research Lab., Albancy Calif. 94710.
\end{abstract}

\begin{abstract}
Severe livestock losses caused by tall larkspur (Delphinium spp.) consumption have caused many producers to try various preventative measures, including the use of mineral-salt supplementation. The objective of this study was to determine if additions or deletions of a mineral-salt supplement (Binn's \#1 Alleviator) would alter the response (i.e., rate of nose pressing) of cattle to tall larkspur exposure. The dose response of 5 Jersey steers was examined by systematically adding $0.25 \mathrm{mg}$ of mineral-salt/kg body weight, and comparing responses in the same steers without salt supplements. Steers were then run under a variable ratio (VR) reinforcement schedule and periodically dosed with tall larkspur at a level causing a significant decrease in responding without provoking overt signs of intoxication. Response rate with and without mineral-salt supplement was the major dependent variable; 3 to 5 "on-off" cycles were conducted for each subject. Steers reduced $(P<0.05)$ their rate of grain intake by $34 \%$ during operant sessions when larkspur was dosed compared to the previous non-dosed 3-day baseline. Rate of nose pressing was reduced $(P<0.01)$ on tall larkspur dose days by $28 \%$ vs. the 3-day non-dosed baseline. This reduction was indicative of the effects of subclinical larkspur intoxication on steers. On days when larkspur was dosed and animals were intoxicated, the addition of mineral did not alter $(P>0.1)$ grain intake (1.64 \pm $0.17 \mathrm{~kg} /$ session) compared to days when no mineral was given (1.76 $\pm 0.13 \mathrm{~kg} / \mathrm{session})$. On larkspur dose days (i.e., when animals were intoxicated), the average response rates were $82.9 \pm$ 3.7 and $85.8 \pm 4.0$ responses/min $(P>0.1)$ when off and on mineral, respectively. We concluded that mineral-salt supplementation had no effect on the response of steers to doses of tall larkspur that produced subclinical intoxication.
\end{abstract}

Tall larkspur (Delphinium barbeyi, D. occidentale) toxicosis in cattle is a serious poisonous plant problem on mountain rangelands in the western U.S. The toxins in tall larkspur are diterpenoid alkaloids, and methyllycaconitine (MLA) is the major toxic alkaloid (Manners et al. 1993, 1995). Methyllycaconitine blocks acetylcholine receptors in the central and peripheral nervous systems (Dobelis et al. 1993), leading to respiratory paraly-

The protocol for animal care and treatment was approved by the Utah State Univ. Institutional Animal Care and Use Committee. We thank Kermit Price and Curt Reed for excellent technical assistance during the study. We also thank Dr. Clive Arave for providing us with the opportunity to use the operant facilities. Manuscript accepted 22 Jul. 1997. sis and eventual death at higher doses. An oral MLA dose greater than $20 \mathrm{mg} / \mathrm{kg}$ body weight, given as dried tall larkspur, will cause ataxia and collapse in cattle (Pfister et al. 1994a), which may be reversed with injections of the cholinergic drug, physostigmine (Pfister et al. 1994b).

Severe losses due to larkspur consumption have caused many livestock producers to try various preventative measures, including the widespread use of mineral-salt supplementation (Pfister and Manners 1991, 1995). Some have claimed that these customformulated, often expensive supplements decrease cattle losses from tall larkspur ingestion (Anderson 1982), but controlled and replicated studies have not been conducted. We have shown that mineral-salt supplements do not reduce the amount of larkspur consumed under field grazing trials (Pfister and Manners 1991, 1995), but there is no information available as to whether animal susceptibility is altered by using mineral-salt supplementation. Therefore, the objective of this study was to determine if an addition of one such supplement (Binn's \#1 Alleviator) would alter the response of cattle to a subclinical dose of tall larkspur under controlled laboratory conditions.

\section{Materials and Methods}

\section{Animals and Feeding}

Five, 2-yr. old, ruminally-cannulated Jersey steers (360 kg) were housed together in a single pen $(8 \mathrm{~m} \times 15 \mathrm{~m})$ with free access to water; the pen was adjacent to the laboratory. Animals were weighed weekly without an overnight fast. Each subjects' feed offering depended in part on the amount of grain (rolled barley) consumed during behavioral testing, termed an operant session. Subjects were given 2 to $3 \mathrm{~kg}$ of alfalfa pellets individually from Monday to Thursday of each week in the afternoon after running in the operant chamber. The exact amount of pellets offered depended on body weight and the quantity of grain consumed during the daily session. On Friday, Saturday, and Sunday, steers were group-fed long-stem alfalfa hay at $1.8 \%$ of body weight. We intended for the steers to have a daily ration slightly above maintenance, and the steers gained slowly ( 5 to 7 $\mathrm{kg}$ /month) during the study.

\section{Plant Collection and Analysis}

Tall larkspur (Delphinium barbeyi L. Huth.) was collected in the tlower stage from the Wasatch Plateau in central Utah at $3,100 \mathrm{~m}$ elevation during July, 1991 and 1994 . Plant material was air-dried, ground through a $2-\mathrm{mm}$ screen in a hammermill, and 
stored in plastic bags at room temperature. Air-drying has no effect on toxicity (Manners, unpublished data). The toxic alkaloid concentration in tall larkspur was determined by the Fourier transform infrared method of Gardner et al. (1997).

\section{Apparatus, training, and plant dosing}

The study was performed in a specially designed $1 \mathrm{~m} \times 3 \mathrm{~m}$ operant chamber. Subjects were trained using standard operant procedures (Gilbert and Arave 1986) to touch a metal disk with their noses. Each nose press constituted a single response. During training, subjects received feed from a device (Cate et al. 1978) which was controlled manually (in initial stages of training) or by computer. Initial behavior was shaped by providing access to rolled barley in the feed magazine as responses gradually came closer to touching the disk (i.e., successive approximations). Eventually, subjects became proficient at the task and thenceforth the schedule was controlled by computer. Trained animals were given 1 second access to grain as reinforcement for successful completion of the schedule. Thus, if the current schedule required 25 responses, the steer was reinforced with 1 second access to grain for each 25 responses. The MED-PCTM software system was used for computer control of the operant chamber (Tatham and Zurn 1989). Feed was available through an access opening when pushed upward by a pneumatic ram, and feed was withdrawn out of reach until the correct number of responses were made.

Subjects were trained using a variable ratio (VR) reinforcement schedule (Fester and Skinner 1957) that gradually increased from 3 to over 20. This program provides reinforcement for the completion of a variable number of responses. Many forms of gambling use VR schedules. For example, slot machines and lotteries exhibit 2 important features of VR schedules: (1) the chance of winning (i.e., gaining a reward) is directly proportional to the number of times one plays; and (2) the number of responses required for the next reinforcer (i.e., reward) is uncertain. Three subjects were tested on a VR29 schedule (mean 29; range 3 to 51); one subject was tested on a VR27 schedule (mean 27; range 3 to 49 ), and the fifth on a VR21 schedule (mean 21; range 3 to 39). For example, for the subjects on the VR29 schedule, on average each 29 responses resulted in 1 reinforcer being provided. Training ended when a subject could not be moved to a higher VR schedule without provoking long post-reinforcement pauses, or having the subject quit responding altogether. In other words, these were the largest obtainable VR's for each subject. Postreinforcement pauses refer to a break or hesitation in responding after being rewarded; VR schedules are characterized by shorter post-reinforcement pauses compared to other schedules (Mazur 1986). Operant sessions were $20 \mathrm{~min}$ in length, and subjects were run in the same order beginning at 1230 hour each day.

After daily training was completed, subjects were run from Monday through Thursday each week. If responding was stable on Monday to Wednesday, subjects were dosed intraruminally at 0530 hour on Thursday with ground larkspur, because the maximum effect from tall larkspur intoxication with whole plant is noted about 7 hours postdosing. Stability was defined as having a daily response rate (i.e., mean responses/min) within $5 \%$ for 3 consecutive days. If subjects were not stable they were run but not dosed on Thursday. Doses ( $\mathrm{g} / \mathrm{kg} \mathrm{b.w.;} \mathrm{air-dried} \mathrm{plant} \mathrm{weight)}$ were calculated to cause a decrease in operant responding (i.e., reduced number of nose presses) without causing muscular tremors and collapse (Pfister et al. 1994a). Subjects receiving mineral were dosed intraruminally each day with $0.25 \mathrm{~g} / \mathrm{kg} \mathrm{b.w.;}$ subjects not receiving mineral-salt supplement had no access to mineral supplement. Initially we used a random drawing to determine if the subject was given mineral $(n=3)$ or not $(n=2)$. Each subject continued on their respective treatment (i.e., mineral or not) until they stabilized in VR performance and then they were dosed; subsequently they were switched to the other treatment (i.e., mineral or not). Subjects were maintained on a particular treatment (i.e., on or off mineral) for a minimum of 2 weeks before larkspur was dosed. We reasoned that this should be sufficient time for ruminants to adapt physiologically to either an increase or decrease in mineral nutrient status. Researchers in mineral nutrition often use 5 days as an equilibration period when adding or deleting a mineral element in ruminant diets (Grace 1991). It was not our intent to produce a specific deficiency or excess of any mineral element. All steers were taken through 3 to 5 (median $=4$ ) complete "on-off" dosing cycles, providing replications within and between subjects.

\section{Mineral supplement}

The mineral-salt supplement was 'Binn's \#1 Alleviator'], which according to the label is formulated "to help reduce losses in areas of larkspur infestation." The complete composition of this mineral-salt supplement is given by Pfister and Manners (1991). Briefly, the supplement contains a large amount of $\mathrm{Na}$ $(197,900 \mathrm{mg} / \mathrm{kg}), 4.36 \% \mathrm{Ca}, 4.33 \% \mathrm{Mg}, 3.83 \% \mathrm{P}$, and various other trace elements.

\section{Statistical analyses}

The study had 2 major dependent variables: a VR response rate (i.e., nose presses/min, with and without mineral on the days larkspur was dosed), and b) grain intake within operant sessions (i.e., $\mathrm{kg} / \mathrm{subject}$, with and without mineral on the days larkspur was dosed). For those dose days when larkspur was given to each subject, the influence of mineral on VR response rate was analyzed using an ANOVA model that included animal, mineral (i.e., on or off), cycle (i.e., each on-off dose constituted 1 cycle), mineral $X$ cycle, and residual error (SAS 1988). Thus, the mineral component of the model indicated if subjects differed in dose response to larkspur when either 'on' or 'off' mineral. Since each animal's response was evaluated a number of times while 'on' mineral as well as 'off' mineral, each linked on-off period was termed a cycle, and the model included this potential source of variation. If significant $(P<0.05)$ interactions occurred, they were examined using the PDIFF procedure of SAS (1988). Likewise, for days when larkspur was dosed, grain intake ( $\mathrm{kg} / \mathrm{session})$ was examined using the same ANOVA model used for VR response rate. In addition, we wished to compare baseline VR response rate and grain intake (both 3-day averages) with grain intake and VR response rate on the day that tall larkspur was dosed (i.e., single day dose response). These comparisons were made using paired t-tests using baseline data and the subsequent dose response for each subject.

\section{Result}

\section{Feed intake}

Steers reduced $(P<0.05)$ their grain intake by $34 \%$ during operant sessions when larkspur was given compared to the previ-

\footnotetext{
${ }^{1}$ Walton Feed West, Inc., Cache Junction, Ut. 84304.
} 
ous 3-day average in the absence of tall larkspur. On those days when cattle were dosed with larkspur, added mineral had no influence $(P>0.1)$ on subjects' grain intake $(1.64 \pm 0.17 \mathrm{~kg} / \mathrm{ses}$ sion) compared to days when no mineral was given $(1.76 \pm 0.13$ $\mathrm{kg} /$ session).

\section{Operant responding}

There was no cycle or cycle $X$ mineral effect $(P>0.1)$. Operant responding i.e., rate of nose pressing) was reduced $(P<0.01)$ by $27.9 \%$ on days when cattle were dosed with tall larkspur vs. the 3-day baseline. We interpret this reduction in responding as an indication, provided by each animal, of an undefined larkspurinduced malaise or discomfort and loss of appetite caused by tall larkspur dosing. Since the larkspur toxin acts at nicotinic cholinergic receptors (Dobelis et al. 1993), we speculate that larkspurinduced malaise may occur in the gastrointestinal tract, peripheral musculature, and perhaps the central nervous system.

Steers had an average baseline response rate of $116.0 \pm 3.1$ and $118.3 \pm 3.4 \mathrm{responses} / \mathrm{min}$, when off and on mineral, respectively. On days when cattle were dosed with larkspur, the average response rates were $82.9 \pm 3.7$ and $85.8 \pm 4.0$ when off and on mineral, respectively $(\mathrm{P}>0.1)$. Responses rates of individual animals are shown in Fig. 1.

The tall larkspur used in this study to dose steers averaged 5.6 $\mathrm{mg}$ toxic alkaloid/g (dry weight). Generally, a dose of about 18 mg toxic alkaloid/kg body weight will provoke significant reduction in operant responding without producing overt clinical signs (Pfister and Cheney 1997).

\section{Discussion}

Mineral-salt supplement had no effect on operant responding by steers given periodic subclinical doses of tall larkspur. The effect on grain intake of dosing cattle with larkspur during operant sessions was not attenuated by mineral-salt supplementation. Operant analysis is a sensitive measure of subclinical tall larkspur intoxication (Pfister and Cheney 1998), and results from this study are consistent with previous results in our laboratory. Steers generally reduced operant responding by $20 \%$ to $30 \%$ when dosed with tall larkspur at a level just below where overt clinical signs of intoxication were apparent. For most steers, that level is

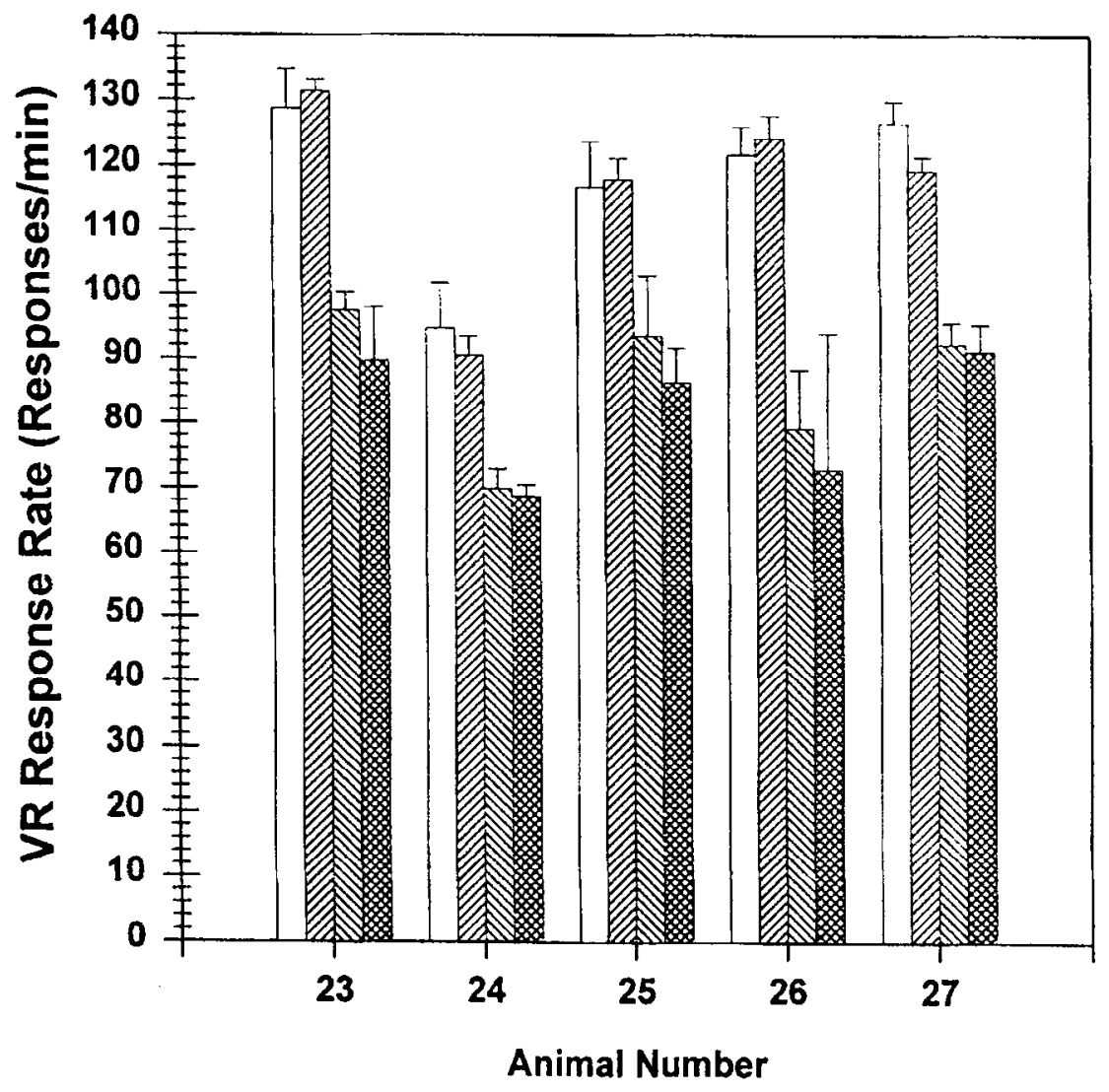

Baseline: mineral added

Larkspur dose: mineral added

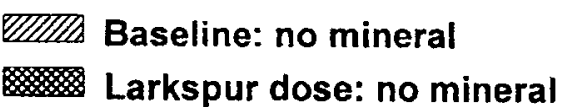

Fig. 1. Variable ratio (VR) response rate (responses/min \pm SE) for 5 steers. The measured response was the rate of nose presses by cattle in an operant chamber. Baseline was measured both with and without mineral-salt supplement and reflects a 3 -day average in the absence of larkspur doses. The bars for larkspur dose show the corresponding response rate on the day tall larkspur was dosed intraruminally (n = 3 to 5; median = 4), both with and without the influence of added mineral-salt supplement. 
about $18 \mathrm{mg}$ toxic alkaloid/ $\mathrm{kg}$ body weight (Pfister and Cheney 1997). The operant response required little muscular effort, and in essence the operant procedure provided an opportunity for steers to subtly indicate their degree of intoxication from tall larkspur.

We used subclinical doses of tall larkspur in this study because once cattle pass a threshold where they periodically collapse into sternal recumbency, they are unable to complete the schedule requirements because they can't reach the apparatus to perform a nose press. In our opinion, providing mineral when cattle receive higher doses of tall larkspur (i.e., near or above lethal doses) will not alter dose response. In order to test higher doses, however, it would be necessary to employ quantitative physiological measures (e.g., electromyogram) to determine the effects of tall larkspur on skeletal muscle in recumbent cattle. Another approach would be to determine if mineral status shifts the median lethal dose $\left(\mathrm{LD}_{50}\right)$ in cattle; this is obviously unappealing for ethical, humane, and financial reasons.

The mechanism by which cattle are intoxicated by larkspur alkaloids has been determined (Dobelis et al. 1993). In light of that knowledge, it does not seem likely that blockage of nicotinic cholinergic receptors at the neuromuscular junction would be affected by mineral status, because the mineral would not likely affect binding affinity. It is possible that supplemental magnesium might, under some circumstances, help reduce deaths from larkspur-induced bloat, but this has not been studied. Treatment of intoxicated animals with the cholinergic drug, physostigmine, has proven to be effective in immediately reversing the effects of non-lethal tall larkspur intoxication (Pfister et al. 1994b). The use of physostigmine to treat larkspur poisoning is logical because the drug inhibits the enzyme acetylcholinesterase, thus maintaining high concentrations of acetylcholine to compete with the larkspur alkaloids for binding sites on receptors.

Some livestock producers report that cattle may be attracted to tall larkspur because of a "craving" for salt or other minerals such as phosphorus. We have previously shown that addition or deletion of mineral-salt supplements in grazing cattle diets has no influence on consumption of tall larkspur (Pfister and Manners 1991, 1995). We recommend that mineral-salt supplements be offered to cattle for nutritional needs rather than for assumed benefits against death loss from tall larkspur.

\section{Literature Cited}

Anderson, E.C. 1982. Forty million cows can't be wrong! Anderson Res. Lab., Bozeman, Mont. (mimeo)

Cate, L.R., M. Mullford, W. Temple, and L.R. Matthews. 1978. A feed delivery system for the study of choice in cows. Behav. Res. Methods Instrument. 10:27-28.

Dobelis, P., J.E. Madl, G.D. Manners, J.A. Pfister, and J.P. Walrond. 1993. Antagonism of nicotinic receptors by Delphinium alkaloids. Neurosci. Abst. 631:12.

Fester, C.S. and B.F. Skinner. 1957. Schedules of reinforcement. New York: Appleton-Century-Crofts.

Gardner, D.R., G.D. Manners, M.H. Ralphs, and J.A. Pfister. 1997. Quantitative analysis of norditerpenoid alkaloids in larkspur (Delphinium spp.) by Fourier transform infared spectroscopy. Phytochem. Anal. 8:55-62.

Gilbert, B.J. and C.W. Arave. 1986. Ability of cattle to distinguish among different wavelengths of light. J. Dairy Sci. 69:825-832.
Grace, N.D. 1991. Micromineral kinetics and animal requirements. pp. 153-162 In: Y.W. Ho, H.K. Wong, N. Abdullah, and Z.A. Tajuddin (eds.). Recent Advances in the Nutrition of Herbivores. Vinlin Press, Kuala Lumpur, Malaysia.

Manners, G.D., K.E. Panter, and S.W. Pelletier. 1995. Structure-activity relationships of norditerpenoid alkaloids occurring in toxic larkspur (Delphinium) species. J. Nat. Prod. 58:863-869.

Manners, G.D., K.E. Panter, M.H. Ralphs, J.A. Pfister, and J.D. Olsen. 1993. The occurrence and toxic evaluation of norditerpenoid alkaioids in the tall larkspurs (Delphinium sp.). J. Food Agr. Chem. 41:96-100.

Mazur, J.E. 1986. Learning and behavior. Prentice-Hall, Inc., Englewood Cliffs, N.J.

Pfister, J.A. and C.D. Cheney. 1998. Operant analysis of acute tall larkspur intoxication in cattle. Behav. 4:43-56.

Pfister, J.A. and G.D. Manners. 1991. Mineral supplementation of cattle grazing larkspur-infested rangeland during drought. J. Range Manage. 44:105-111.

Pfister, J.A. and G.D. Manners. 1995. Effect of carbachol administration in cattle grazing tall larkspur-infested rangeland. J. Range Manage. 48:343-349.

Pfister, J.A., K.E. Panter, and G.D. Manners. 1994a. Effective dose in cattle of toxic alkaloids from tall larkspur (Delphinium barbeyi). Vet. Hum. Tox. 36:10-11.

Pfister, J.A., K.E. Panter, G.D. Manners, and C.D. Cheney. 1994b. Reversal of tall larkspur (Delphinium barbeyi) poisoning in cattle with physostigmine. Vet. Hum. Tox. 36:511-514.

Tatham, T.A. and K.R. Zurn. 1989. The MED-PC experimental apparatus programming system. Behav. Res. Methods Instrument. 21:294-302.

SAS. 1988. SAS User's Guide SAS/STAT ${ }^{\circ}$ (Release 6.03). SAS Inst lnc., Cary, NC. 